\title{
STUDY ON ANTIOXIDANT ACTIVITIES OF THE AERIAL PARTS AND SOME COMPOUNDS ISOLATED FROM Archidendron clypearia ((Jack) I. Niels
}

\author{
Part 2. ISOLATING, DETERMINING STRUCTURE AND \\ ANTIOXIDANT CAPABILITY OF SOME COMPOUNDS \\ FROM ETHYL ACETATE AND CHLOROFORM EXTRACT
}

\author{
Le Trung Hieu ${ }^{1,}$, Vo Thi Mai Huong ${ }^{1}$, Nguyen Thi Hoai ${ }^{2}$, Tran Thi Van Thi ${ }^{1}$ \\ ${ }^{I}$ The College of Sciences, Hue University, 77 Nguyen Hue, Hue city \\ ${ }^{2}$ The College of Medicine and Pharmacy, Hue University, 41 Nguyen Hue, Hue city \\ "Email: letrunghieu.chem@gmail.com
}

Received: 8 November 2015; Accepted for publication: 30 March 2016

\begin{abstract}
The antioxidant activity in vitro of methanol extract of Archidendron clypearia was evaluated by tests on isolated liver cells of mouses with $\mathrm{ED}_{50}$ value of $2.18 \mu \mathrm{g} / \mathrm{mL}$ compared to that of curcumin of $1.87 \mu \mathrm{g} / \mathrm{mL}$. Using combined chromatographic methods, four compounds from ethyl acetate extract and two compounds from chloroform extract of the Archidendron clypearia were isolated. Their structures were elucidated to be daucosterol, 1-octacosanol, docosenoic acid, methyl gallate, betulinic acid and lup-20(29)-en-3-one by 1D- and 2D-NMR spectroscopic methods and in comparison with those reported in the literature. This is the first report of these compounds from the plant. All four compounds from ethyl acetate showed quite high antioxidant activity, for which methyl gallate was the highest one.
\end{abstract}

Keywords: Archidendron clypearia, antioxidant activity, daucosterol, methyl gallate, 1octacosanol, acid docosenoic, betulinic acid, lup-20(29)-en-3-one.

\section{INTRODUCTION}

Archidendron clypearia (Jack) I. Niels belongs to subfamily Mimosaceae. This originated from tropical countries as Vietnam, China... It is used in the folk medicine in Vietnam - Pako ethnic group for the treatment of diabetes, laryngitis, high blood pressure ... [1]. As part of our research on the chemical constituents and biological activity of Archidendron clypearia, Herein, we reported, for the first time, the isolation of four compounds from ethyl acetate extract and two compounds from chloroform extract of Archidendron clypearia. The antioxidant activities of these compounds from ethyl acetate extract were also reported. 


\section{MATERIALS AND METHODS}

\subsection{Plant materials and laboratory animals}

Aerial parts of Archidendron clypearia were collected from Quang Tri province in March 2015. Scientific name of the collected samples was determined by a staff of the Institute of Ecologyand Biological Resources, National Academy of Science and Technology of Viet nam by morphological observation and DNA analysis. The samples were then dried at $50{ }^{\circ} \mathrm{C}$ for 6 hours and grinded to powder.

Healthy 8-week old mouse, weighing from 25 to 30 grams which were kept in a laboratory room kept at $23 \pm 2{ }^{\circ} \mathrm{C}$ with a $12 \mathrm{hrs} \mathrm{light} \mathrm{with} \mathrm{the} \mathrm{humidity} \mathrm{of} 50-60 \%$. Experimental animals were fed as a standard diet ad libitum and the tap water at the animal area of Biotechnology Institute with food and water are always.

\subsection{Tests for antioxidation activity in vitro on liver cells of rats $[2,3]$}

Healthy BALB/c mice is used to isolate the liver cells. Liver cell damage had been by feeding with ethanol $80^{\circ}$, then using tweezers, scissors mouse surgery, liver cell extract. Liver cells of rats were washed with PBS (phosphate buffer saline) with $10 \%$ PSF antibiotics (Penicillin- Streptomicin- Fungizone) (Invitrogen), splited in PBS, centrifuged and removed supernatant. Residue cells dissolved in $\mathrm{NH}_{4} \mathrm{Cl}$ to break down erythrocytes. After centrifugation, residue cells were dissolved brought back into the environment with $10 \%$ FBS MEME (fetal bovine serum) and other components necessary. After being isolated, liver cells will be incorporated into a plate (96-well) with density $1 \times 10^{4}$ cells/ well for culture overnight in incubator $5 \% \mathrm{CO}_{2}$ at $37{ }^{\circ} \mathrm{C}$. The substance with different concentrations added and incubated in $2 \mathrm{hrs} .100 \mu \mathrm{M} \mathrm{H}_{2} \mathrm{O}_{2}$ would be added to each well and to impact in $2 \mathrm{hrs}$. To determine the number of liver cells survived under effects of $\mathrm{H}_{2} \mathrm{O}_{2}$ as well as protective effects of substance research, $1 \mathrm{mg} / \mathrm{mL}$ (50 mL/well) MTT formazan (Thiazolyl blue formazan) was added to the wells and incubated for $4 \mathrm{hrs}$ at $37^{\circ} \mathrm{C}$. Removed the supernatant, added $100 \mu \mathrm{LDMSO} /$ well and measured optical density (OD value) by machine Microplate Reader at $492 \mathrm{~nm}$. All experiments were repeated 3 times to avoid errors.

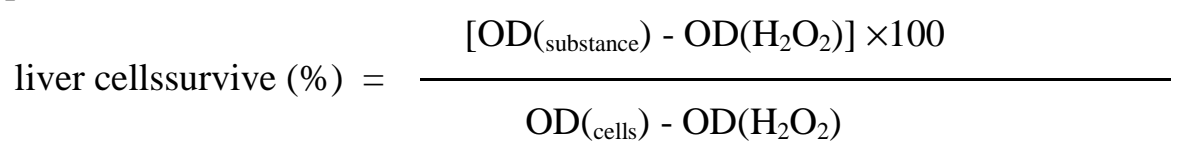

In which:

OD (substance) is the optical density values measured in wells containing substance;

$\mathrm{OD}\left(\mathrm{H}_{2} \mathrm{O}_{2}\right)$ is the optical density values measured in the negative control wells, only cell death by $\mathrm{H}_{2} \mathrm{O}_{2}$;

OD (cells) is the opticaldensity values measured in wells that healthy cells, not by $\mathrm{H}_{2} \mathrm{O}_{2}$ were lethal.

$\mathrm{ED}_{50}$ values (Median effective dose - The dose required to achieve $50 \%$ of the desired response in $50 \%$ of the population) will be determined using Table Curve sorfware.

\subsection{Extraction and isolation}


Dried sample of Archidendron clypearia $(5.0 \mathrm{~kg}$ ) was extracted with $\mathrm{MeOH}$ three times at room temperature; resulted extract was then concentrated under reduced pressure to give $\mathrm{MeOH}$ extract. The methanol extract was suspended in water and then partitioned with $n$-hexane, chloroform, ethyl acetate and $n$-butanol, respectively.

The ethyl acetate fraction was then fractionated into eight fractions (E1 to E8) by silica-gel column chromatography using $n$-hexane: acetone (100:0, 40:1, 20:1, 10:1, 5:1, 1:1, 0:100) and methanol as mobile phase, respectivley. The E4 fraction was further fractionated using another silica-gel column with chloroform: acetone (10:1) as mobile phase to obtain five sub-fractions (E4.1 to E4.5). The fraction E4.2 was, again, separated into four fractions (E4.2.1 to E4.2.4) by reversed-phase column chromatography using acetone: water (3:2) for elution. The E4.2.3 fraction was then subjected to be separated on column with chloroform: ethyl acetate: methanol (15:1:0.1) solvent system to obtain other five fractions (E4.2.3.1 to E4.2.3.5). The E4.2.3.4 was again processed by a reversed-phase column using YMC (YMC RP-18 resins $(30 \div 50 \mu \mathrm{m}$, Fujisilica Chemical Ltd.)) and methanol: water (3:1) to obtain three fractions. The E4.2.3.4.2 fraction was finally chromatographed on a Sephadex LH-20 column eluted with methanol to yield compound $\mathrm{N}^{0} .1(25 \mathrm{mg})$.

The E4.4 fraction was chromatographed on a Sephadex LH-20 column eluted with methanol to obtain four fractions (E4.4.1 to E4.4.4). The E4.4.2 fraction was then fractionated using YMC and methanol: water (8:1) as stationary phase and mobile phase, respectively. Four fractions (E4.4.2.1 to E4.4.2.4) were obtained and among them, the fraction E4.4.2.2 was purified by preparative TLC developed with chloroform: methanol: formic acid (5:1:0.1) and identified as compound $\mathrm{N}^{0} .2(12 \mathrm{mg})$.

The E3 fraction was chromatographed on a silica gel column and eluting with chloroform: methanol (5:1) obtained five fractions (E3.1 to E.3.5). The E3.4 fraction was chromatographed on a Sephadex LH-20 column eluted with methanol: water (4:1) obtained four smaller fraction (E3.4.1 to E3.4.4.). The E34.2 fraction was chromatographed on an YCM column using acetone: water: formic acid (6:15:0.5) obtain five smaller fractions (E3.4.2.1 to E3.4.2.5). The E3.4.2.1 fraction was chromatographed on a Sephadex LH-20 column eluted with methanol obtained three smaller fractions (E3.4.2.1.1 to E3.4.2.1.3 3). The E3.4.2.1.2 fraction was purified by column chromatography with chloroform: methanol: water (3:1:0.1) to yield compond $\mathrm{N}^{0} . \mathbf{3}$ (15 $\mathrm{mg})$.

The E3.4.2.4 fraction was purified by Sephadex column eluted with methanol obtained comound $\mathrm{N}^{0} .4(17 \mathrm{mg})$.

The Chloroform fraction was then fractionated into seven fractions ( $\mathrm{C} 1$ to $\mathrm{C} 7)$ by silica-gel column chromatography using $n$-hexane - acetone (100: $0,40: 1,20: 1,10: 1,5: 1,1: 1,0: 100)$ as mobile phase, respectively.

The $\mathrm{C} 4$ fraction was further fractionated using another silica-gel column with $n$-hexane acetone (15: 1) as mobile phase to obtain five fractions (C4.1 to C4.5). The fraction $\mathrm{C} 4.2$ was, again, separated into five fractions (C4.2.1 to $\mathrm{C} 4.2 .5)$ by reversed-phase column chromatography using acetone: water (3:2) for elution. The C4.2.2 fraction was then subjected to be separated on column with chloroform- methanol (20:1) to obtain other four fractions (C42.2.1 to $\mathrm{C} 4$.2.2.4). The C4.2.2.2 was again processed by a reversed-phase column using

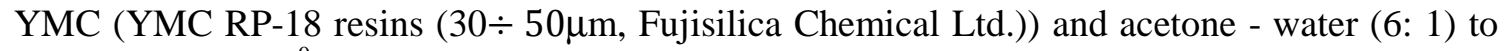
yield compound $\mathrm{N}^{0} .5(\mathrm{~m}=17 \mathrm{mg})$.

The $\mathrm{C} 2$ fraction was chromatographed on an YCM column using acetone-water (4: 1) as mobile phase to obtain eight fractions ( $\mathrm{C} 2.1$ to $\mathrm{C} 2.8$ ). The $\mathrm{C} 2.4$ fraction was, again, 
chromatographed on a silica gel column and eluting with $n$-hexane -acetone (20: 1) obtained five fractions (C2.4.1 to $\mathrm{C} 2.4 .5)$. The $\mathrm{C} 2.4 .1$ was chromatographed on an YCM column using acetone - methanol - water (3: 1: 0.1) obtain five fractions (C2.4.1.1 to C2. 4.1.5). The C2.4.1.1.3 fraction was finally chromatographed on a Sephadex LH-20 column eluted with methanol- water (2: 1) to yield compound $\mathrm{N}^{0} .6(\mathrm{~m}=10 \mathrm{mg})$.

\section{RESULTS AND DISCUSSION}

\subsection{Antioxidation in vitro on liver cells of rats of aerial parts of Archidendron clypearia}

The results of the screening antioxidant activity of methanol extracts of $20 \mu \mathrm{g} / \mathrm{mL}$ showed that Archidendron clypearia is the best among medicinal plants for sustaining life for hepatocytes as reached $115.246 \%(\geq 50 \%)$ [1]. The Table Curve program was used to study and determine ED50 values. At experimental concentrations of $20 \mu \mathrm{g} / \mathrm{mL} ; 4 \mu \mathrm{g} / \mathrm{mL} ; 0.8 \mu \mathrm{g} / \mathrm{mL}$; $0.16 \mu \mathrm{g} / \mathrm{mL}$, the survival ratios of liver cells were higher in test samples compared with in the control ones using curcumin, respectively. Furthermore, the results obtained to showed that Archidendron clypearia is better than curcumin in antioxidant activity on liver cells of rats. The ED50 of Archidendron clypearia is $2.18 \mu \mathrm{g} / \mathrm{mL}$, it is significant higher than this value of curcumin $(1.87 \mu \mathrm{g} / \mathrm{mL})$ [1]. The in vitro antioxidant activity of $n$-hexane, chloroform, ethyl acetate, n-butanol, and water extracts from Archidendron clypearia were tested and the given results are quite good. Especially, the ethyl acetate fraction exhibits the best activity with the lowest ED50 value is $0.63 \mu \mathrm{g} / \mathrm{mL}$. It can be seen that this value is only about as 1/6 ED50 compared with that of curcumin $(4.43 \mu \mathrm{g} / \mathrm{mL})$. Therefor the chloroform and ethyl acetate fractions should be selected to investigate the chemical composition and antioxidant activity.

\subsection{The chemical structure of compounds isolated from methyl acetate extract of Archidendron clypearia}

Six compounds were extracted and isolated from ethyl acetate fraction and chloroform extract fraction. The structure of these compounds were identified by spectral data 1D, 2D-NMR and comparison with the universal standards of data.

Compound $\mathrm{N}^{0} .1$ was obtained as a white crystal, dissolve well in mixed $\mathrm{CHCl}_{3}$ and $\mathrm{CH}_{3} \mathrm{OH}$. The ${ }^{1} \mathrm{H}-\mathrm{NMR}$ spectrum of $\mathrm{N}^{0} .1$ showed the signals of an olefinic proton at $\delta 5.37(1 \mathrm{H}$, $\mathrm{d}, \mathrm{J}=5.0 \mathrm{~Hz})$, six methyl groups at $\delta 1.01(3 \mathrm{H}, \mathrm{s}), 0.93(3 \mathrm{H}, \mathrm{d}), 0.85(3 \mathrm{H}, \mathrm{t}), 0.83(3 \mathrm{H}, \mathrm{d}), 0.82$ $(3 \mathrm{H}, \mathrm{d}), 0.69(3 \mathrm{H}, \mathrm{s})$ and the signals of protons attached carbon on regional from 1.0 to $2.5 \mathrm{ppm}$.

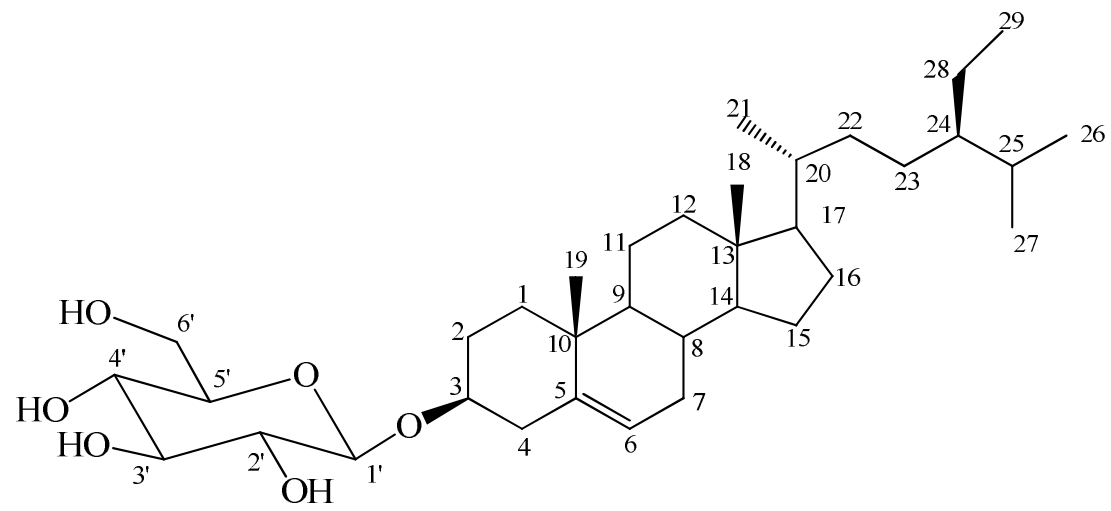

Figure 1. Structure of compound $\mathrm{N}^{0} .1$ (daucosterol). 
In addition, ${ }^{1} \mathrm{H}-\mathrm{NMR}$ spectrum showed anomeric proton signal at $\delta 4.41(1 \mathrm{H}, \mathrm{d}, \mathrm{J}=7.5 \mathrm{~Hz})$ and the other proton of $\beta$-Glucopyranosyl about $\delta 3.0$ to $4.0 \mathrm{ppm}$. From the spectral data allows prediction on this compound is a sterol glycosides. Compared with spectral data in document [4], compound $\mathrm{N}^{0} .1$ is defined as daucosterol, CTPT $\mathrm{C}_{35} \mathrm{H}_{60} \mathrm{O}_{6}$ (Fig. 1).

Compound $\mathrm{N}^{0} .2$ was obtained as a white crystal. The ${ }^{1} \mathrm{H}-\mathrm{NMR}$ spectrum showed the presence of aromatic protons at $\delta_{\mathrm{H}} 7.07(2 \mathrm{H}, \mathrm{s})$ and the signal of the methoxy group at $\delta_{\mathrm{H}} 3.83$ $(3 \mathrm{H}, \mathrm{s})$. The ${ }^{13} \mathrm{C}-\mathrm{NMR}$ and DEPT spectrum showed the presence of carboxyl group at $\delta_{\mathrm{C}} 169.0$; aromatic carbons linked to oxygene in $\delta_{\mathrm{C}} 146.4 ; 139.7$ and other aromatic carbon $\delta_{\mathrm{C}} 121.5 ; 110.1$ $\mathrm{ppm}$. In addition, the carbon signal of methoxy groups were also recorded at $52.2 \mathrm{ppm}$. ${ }^{1} \mathrm{H}-\mathrm{NMR}$ $\left(500 \mathrm{MHz}, \mathrm{CD}_{3} \mathrm{OD}\right) \delta(\mathrm{ppm}): 7.07(2 \mathrm{H}, \mathrm{s}, \mathrm{H}-2$ and $\mathrm{H}-6), 3.83(3 \mathrm{H}, \mathrm{s}, \mathrm{H}-8) .{ }^{13} \mathrm{C}-\mathrm{NMR}(125 \mathrm{MHz}$, $\left.\mathrm{CD}_{3} \mathrm{OD}\right) \delta(\mathrm{ppm}): 169.0$ (s, C-7), 146.4 (s, C-3 and C-5), 139.7 (s, C-4), 121,5 (s, C-1), 110.1 (d, $\mathrm{C}-2$ and C-6), 52.2 (q, C-8).

The spectral data enables determination of compound $\mathrm{N}^{0} .2$ as methyl gallate (Fig. 2).<smiles>COC(=O)c1cc(O)c(O)c(O)c1</smiles>

Figure 2. Structure of compound $\mathrm{N}^{0} .2$ (methyl gallate).

Compound $\mathrm{N}^{0} .3$ was obatined as white powder, soluble in chloroform with a molecular formula of $\mathrm{C}_{28} \mathrm{H}_{58} \mathrm{O}$ from a pseudo molecular ion peak $\mathrm{m} / \mathrm{z} 413.0[\mathrm{M}+\mathrm{H}]^{+}$. The ${ }^{1} \mathrm{H}-\mathrm{NMR}$ spectrum showed the presence signal ofthe methyl group at $\delta_{\mathrm{H}} 10.88(\mathrm{t}, \mathrm{J}=7.0 \mathrm{~Hz}, \mathrm{H}-28)$, oxymethylene group at $\delta_{\mathrm{H}} 3.64(\mathrm{t}, \mathrm{J}=7.0 \mathrm{~Hz}, \mathrm{H}-1)$, a methylene group adjacent oxymethylene group at $\delta_{\mathrm{H}} 1.57(\mathrm{H}-2)$ and other proton parafinic during $\delta_{\mathrm{H}} 1.25$ to $1.34(\mathrm{H}-3 \div \mathrm{H}-27)$. These data a long with spectral data in document [5] allows confirming the compound $\mathrm{N}^{0} .3$ is 1 octacosanol (Fig. 3).

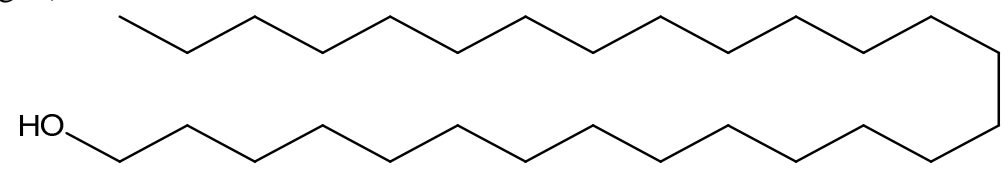

Figure 3. Structure of compound $\mathrm{N}^{0} .3$ (1-octacosanol).

Compound $\mathrm{N}^{0} .4$ was isolated as an oil, colorless, soluble in chloroform with a molecular formula of $\mathrm{C}_{22} \mathrm{H}_{42} \mathrm{O}_{2}$ from a pseudo molecular ion peak $\mathrm{m} / \mathrm{z} 337.6$ [M-e]+. The ${ }^{1} \mathrm{H}-\mathrm{NMR}$ spectrum showed the presence of one methyl at $\delta_{\mathrm{H}} 0.88(\mathrm{t}, \mathrm{J}=7.0 \mathrm{~Hz})$, three methylene groups $\delta_{\mathrm{H}}$ at $1.63,2.00,2.34(\mathrm{t}, \mathrm{J}=7.5)$, olefinic proton at $\delta_{\mathrm{H}} 5.34(\mathrm{~m})$ and signals of methylene groups during 1.14 to 1.42 . Signals from olefinic protons appear as a constantinte reaction multiplet with little proven double bond cis configuration. The ${ }^{13} \mathrm{C}-\mathrm{NMR}$ and DEPT spectrum showed the presence of carboxyl group at $\delta_{\mathrm{C}} 180.3$; double bond of two carbon at 130.0 and 129.7, one methyl group at 14.1 and many methylene groups. The spectral data indicates the compound 
$\mathrm{N}^{0} .4$ as a fatty acid with one double bond. Compound $\mathrm{N}^{0} .4$ was identified as docosenoic acid (Fig. 4).

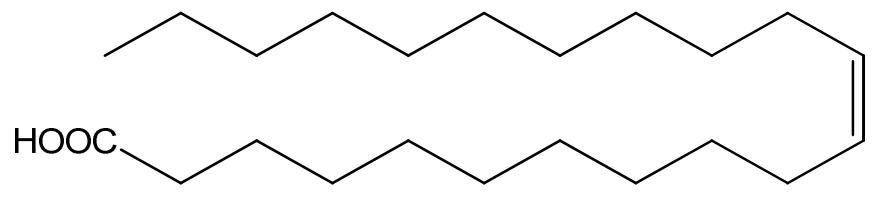

Figure 4. Structure of compound $\mathrm{N}^{0} .4$ (docosenoic acid).

Compound $\mathrm{N}^{0} .5$ was obtained as a white crystal, dissolve well in chloroform, $\mathrm{Rf}=0.5$ ( $n$-hexane - acetone,10:1). The ${ }^{1} \mathrm{H}$-NMR spectrum of $\mathrm{N}^{0} .5$ showed signals of six methyl groups at $\delta_{\mathrm{H}} 1.69 \mathrm{~s}, 0.97 \mathrm{~s}, 0.96 \mathrm{~s}, 0.94 \mathrm{~s}, 0.82 \mathrm{~s}, 0.75 \mathrm{~s}$, signals at $\delta_{\mathrm{H}} 4.60 \mathrm{~s}, 4.73 \mathrm{~s}$ confirmed the existence a exo-methylene group. Resonant signal at $\delta_{\mathrm{H}} 3.17 \mathrm{dd}(10.5,6.0)$ belongs to proton for a hydroxymethine group. Value $\mathrm{J}_{1}=10.5 \mathrm{~Hz}, \mathrm{~J}_{2}=6.0 \mathrm{~Hz}$ corresponds to interact diaxial, axialequatorial, demonstrate proton structure exists in the form of axial or express $\alpha$ configuration.

The ${ }^{13} \mathrm{C}-\mathrm{NMR}$ and DEPT spectrum of $\mathrm{N}^{0} .5$ exhibited the signals for 30 carbons, including six methyl group, eleven methylene group, six methine groups and seven carbons without hydrogen, signals at 179.4, 150.9, 79.0 defined for carboxyl group (C-28), exo-methylene group (C-20) and methine group linked to oxygen (C-3) respectively. In addition, the HMBC correlations from $\mathrm{H}-24\left(\delta_{\mathrm{H}} 0.75\right)$ to $\mathrm{C}-3\left(\delta_{\mathrm{C}} 79.0\right), \mathrm{C}-5\left(\delta_{\mathrm{C}} 55.5\right), \mathrm{C}-23\left(\delta_{\mathrm{C}} 28.0\right)$; from $\mathrm{H}-23\left(\delta_{\mathrm{H}}\right.$ $0.96)$ to $\mathrm{C}-3\left(\delta_{\mathrm{C}} 79.0\right), \mathrm{C}-24\left(\delta_{\mathrm{C}} 15.4\right)$; from $\mathrm{H}-25\left(\delta_{\mathrm{H}} 0.82\right)$ to $\mathrm{C}-9\left(\delta_{\mathrm{C}} 50.7\right), \mathrm{C}-5\left(\delta_{\mathrm{C}} 55.5\right), \mathrm{C}-1$ $\left(\delta_{\mathrm{C}} 38.9\right), \mathrm{C}-10\left(\delta_{\mathrm{C}} 37.3\right)$; from H-26 $\left(\delta_{\mathrm{C}} 0.94\right)$ to C-9 $\left(\delta_{\mathrm{C}} 50.7\right), \mathrm{C}-14\left(\delta_{\mathrm{C}} 42.6\right), \mathrm{C}-8\left(\delta_{\mathrm{C}} 40.8\right), \mathrm{C}-$ $7\left(\delta_{\mathrm{C}} 34.5\right)$ and from H-27 $\left(\delta_{\mathrm{C}} 0.97\right)$ to $\mathrm{C}-14\left(\delta_{\mathrm{C}} 42.6\right), \mathrm{C}-8\left(\delta_{\mathrm{C}} 40.8\right), \mathrm{C}-15\left(\delta_{\mathrm{C}} 30.7\right)$ as having five methyl groups substituted in positions $4,8,10$ and 14 respectively. Similar to interact from H-19 to C-30 $\left(\delta_{\mathrm{C}} 19.4\right), \mathrm{C}-17\left(\delta_{\mathrm{C}} 56.4\right), \mathrm{C}-18\left(\delta_{\mathrm{C}} 47.1\right), \mathrm{C}-13\left(\delta_{\mathrm{C}} 38.4\right)$; from H-29 $\left(\delta_{\mathrm{H}} 4,60\right.$, $4.73)$ to $\mathrm{C}-30\left(\delta_{\mathrm{C}} 79.0\right), \mathrm{C}-18\left(\delta_{\mathrm{C}} 47.1\right)$ and from H-30 $\left(\delta_{\mathrm{H}} 1.69\right)$ to C-20 $\left(\delta_{\mathrm{C}} 150.9\right), \mathrm{C}-29\left(\delta_{\mathrm{C}}\right.$ 109.6) exo-methylene showing substituted group at position $\mathrm{C}-19(\delta \mathrm{C} 49.2)$.

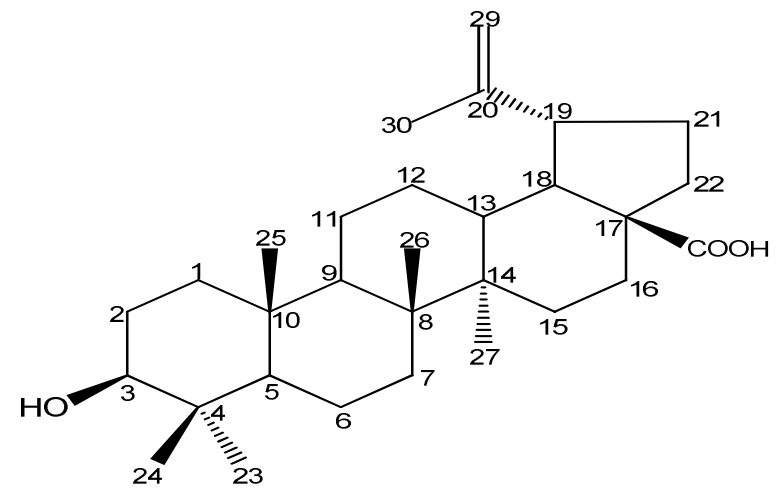

Figure 5. Structure of compound 5 betulinic acid.

Compared with spectral data in document [6], compound $\mathrm{N}^{0} .5$ is defined as $3 \beta$-hydroxy-20 (29) -lupen-28-OIC acid (this is a lupane - type triterpenoid ), also known as betulinic acid (Fig. 5).

Compound $\mathrm{N}^{0} .6$ was obatined as white powder, soluble in chloroform, $\mathrm{Rf}=0.9$ ( $n$-hexaneacetone, 10: 1). Compound $\mathrm{N}^{0} .6$ has structure similar to $\mathrm{N}^{0} .5$. The ${ }^{1} \mathrm{H}-\mathrm{NMR}$ spectrum of $\mathrm{N}^{0} .6$ indicated signals of seven methyl groups at $\delta_{\mathrm{H}} 1.69 \mathrm{~s}, 1.08 \mathrm{~s}, 1.08 \mathrm{~s}, 1.03 \mathrm{~s}, 0.96 \mathrm{~s}, 0,93 \mathrm{~s}, 0.80 \mathrm{~s}$ and signals at $\delta_{\mathrm{H}} 4.57 \mathrm{~s}, 4.70 \mathrm{~s}$ confirmed the existence a exo-methylene group. In addition, the ${ }^{13} \mathrm{C}$ NMR and DEPT spectrum of exhibited the signals for 30 carbons, including seven methyl 
groups, eleven methylene groups, five methine groups and seven carbons without hydrogen, signals at 218.2, 150.9 defined for ketone group (C-3), exo-methylene group(C-20).

These data along with spectral data in document [7] allows confirming the compound $\mathrm{N}^{0} .6$ is LUP-20 (29) -en-3-one (Fig. 6).

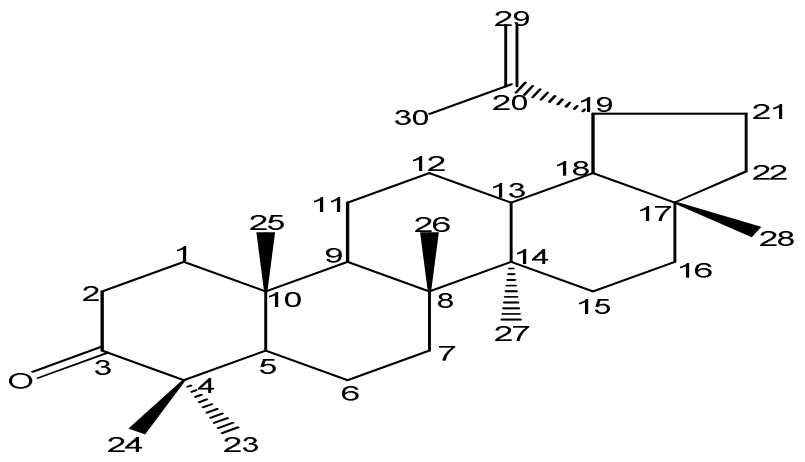

Figure 6. Structure of compound 6 (LUP-20 (29) -en-3-one).

\subsection{Antioxidation activity in vitro on liver cells of rats of isolated compounds from ethyl acetate fraction}

Four pure isolated compounds were tested on antioxidation activity in vitro. Results showed in Table 1.

Among the four compounds were isolated and tested activity, methyl gallate had shown a good antioxidant with value $\mathrm{ED}_{50}$ of $7.31 \mu \mathrm{g} / \mathrm{mL}$ (for curcumin was $6.31 \mu \mathrm{g} / \mathrm{mL}$ ). Three compounds of daucosterol, 1-octacosanol and docosenoic acid expressed lower antioxidant effects in the experimental model.

Table 1. The results of in vitro tests of antioxidant activity on liver cells of rats of isolated compounds from Archidendron clypearia.

\begin{tabular}{|c|c|c|c|c|c|c|}
\hline \multicolumn{7}{|c|}{ Ratio (\%) surviving cells } \\
\hline $\begin{array}{c}\text { Concentration } \\
(\mu \mathrm{g} / \mathrm{mL})\end{array}$ & 1 -octacosanol & docosenoic & daucosterol & $\begin{array}{c}\text { methyl } \\
\text { gallate }\end{array}$ & \multicolumn{2}{c|}{$\begin{array}{c}\text { cucurmin } \\
\text { concentration }(\mu \mathrm{g} / \mathrm{mL})\end{array}$} \\
\hline 160.00 & 24.38 & 1.94 & 27.92 & 65.90 & 80.00 & 67.42 \\
\hline 32.00 & 19.26 & 5.30 & 6.01 & 62.19 & 16.00 & 59.11 \\
\hline 6.40 & 14.84 & 13.07 & 3.00 & 46.11 & 3.20 & 41.73 \\
\hline 1.28 & 8.83 & 9.72 & -7.42 & 38.34 & 0.64 & 16.89 \\
\hline $\mathbf{E D}_{\mathbf{5 0}}(\boldsymbol{\mu g} / \mathbf{m L})$ & $>\mathbf{1 6 0}$ & $>\mathbf{1 6 0}$ & $>\mathbf{1 6 0}$ & $\mathbf{7 . 3 1}$ & & $\mathbf{6 . 3 1}$ \\
\hline
\end{tabular}

\section{CONCLUSION}

Archidendron clypearia (Jack.) I. Niels. had shown significant antioxidant activity with the $\mathrm{ED}_{50}$ is $2.18 \mu \mathrm{g} / \mathrm{mL}$ in in vitro tests on isolated liver cells of rat while the value of curcumin is $1.87 \mu \mathrm{g} / \mathrm{mL}$. Six compounds had isolated from ethyl acetate and chloroform fractions and identified are daucosterol (N0 .1), methyl gallate(N0 .2), 1-octacosanol (N0 .3), docosenoicacid (N0 .4), betulinic acid (NO .5) and lupenone (NO .6). All of them were isolated from this plant 
for the first time. In particular, methyl gallate had shown antioxidant activity with ED50 value of $7.31 \mu \mathrm{g} / \mathrm{mL}$. These results open up prospects for searching new bioactive compounds with antioxidant activity from the nature wild as the medicine plants.

Acknowledgments. The authors would like to thank to Assoc. Dr. Ninh Khac Ban, MA. Nguyen The Cuong, Institute of Ecology and Biological Resources, National Academy of Science and Technology of Viet Nam for identifying the scientific name. This paper is an outcome of the subject of Science and Technology of Thua Thien Hue province, Code TTH.2014-KC.11.

\section{REFERENCES}

1. Nguyen T. H., Trinh T. D., Đo T. T., Nguyen K. T. L., Nguyen B. H., Hoang T. D. H., Screening the Antioxidant Activity of Some Medicinal Plants of Pako and Van Kieu Peoples in Quang Tri Province, Journal of Medicinal Materials 17 (1) (2012) pp.8-13 (in Vietnamese).

2. Gupta R., Sharma M., Lakshmy R., Prabhaharan D., Reddy K. S., - Improved method of total antioxidant assay, Indian J. Biochem. Biophys. 46 (2009) pp.126-129.

3. Haimin C., Xiaojun Y., Peng Z., Jing L. - Antioxidant activity and hepatoprotective potential of agaro-oligosaccharides in-vitro and in-vivo, Nutrition Journal 5 (31) (2006).

4. Odinokov, V. N., Spivak, A. Y., Emelyanova, G. A., Mallyabaeva, M. I., Nazarova, O. V., \& Dzhemilev, U. M. - Synthesis of $\alpha$-tocopherol (vitamin E), vitamin K1-chromanol, and their analogs in the presence of aluminosilicate catalysts Tseokar-10 and Pentasil, Arkivoc 13 (2003) pp.101-118.

5. Ragasa C. Y., Galian R. F., Arenal M., Vernadette Tan and Chien-Chang Shen Triterpenes and Sterols from Samanea saman, Research Journal of Pharmaceutical, Biological and Chemical Sciences 5(4) (2014) pp. 1501 - 1507.

6. Kim J. H., Byun J. C., Hyun C. G., \& Lee N. H. - Compounds with elastase inhibition and free radical scavenging activities from Callistemon lanceolatus, Journal of Medicinal Plants Research 3(11) (2009) pp. 914-920.

7. Prachayasittikul S., Saraban P., Cherdtrakulkiat R., Ruchirawat S., Prachayasittikul V. New bioactive triterpenoids and antimalarial activity of Diospyros rubra Lec, Excli Journal 9 (2010) pp. 1-10. 